\title{
HUMARA Assay
}

National Cancer Institute

\section{Source}

National Cancer Institute. HUMARA Assay. NCI Thesaurus. Code C18305.

Human androgen receptor gene assay. This assay was used to detect X chromosomal inactivation for diagnosis of $\mathrm{X}$-linked conditions, ie. Kennedy disease, agammaglobulinemia, and others. 